\title{
Commercialisation of Tertiary Education as a Correlate of Economic Recession in Nigeria
}

\author{
IGBINEDION, Doye Angela, Ph.D ${ }^{1 *}$ DIETTE-SPIFF, Mercy Inekiengha C. ${ }^{2}$ \\ 1. School of Education, Department of Educational Foundation, Isaac Jasper Boro College of Education, \\ Sagbama, Bayelsa State, Nigeria. \\ 2. School of Early Childhood, Department of Primary Education, Isaac Jasper Boro College of Education, \\ Sagbama, Bayelsa State, Nigeria.
}

\begin{abstract}
This study examined commercialisation of tertiary education as a correlate of economic recession in Nigeria. The study adopted a correlational survey design. The Taro Yamane's formula was employed to draw the sample of 322 lecturers from the purposively chosen two federal universities using the convenience sampling technique. Data collecting instrument was the researcher's structured questionnaire that was face validated by three experts. Data were analysed using the Pearsons' correlation coefficient and linear regression. Findings revealed among others very high relationship between commercialization of tertiary education and economic recession in Nigeria. Based on the findings, some recommendations were made among which was the intensification of quality assurance mechanisms of the tertiary education system by the various commissions responsible for the programme to ensure quality manpower.
\end{abstract}

Keywords: Commercialisation, tertiary education, economic, economic recession, Nigeria

DOI: $10.7176 / \mathrm{JEP} / 10-2-17$

\section{Introduction}

Education all over the world has been acknowledged as the key to national development. This development is the culmination of growth across the various sectors of the nation. It is the goal of proffering solution to the large society that tertiary education is established to address. The Federal Government of Nigeria (2014) affirmed that the broad goal of this education is the acquisition and development of both intellectual and physical capabilities as well as of character of individuals to contribute meaningfully towards the development of their community as well as inculcating in individuals proper value orientations for their own survival and that of their community. This invariably suggests that tertiary education among others, is concerned with manpower development for a corresponding transformation in the society.

Tertiary education is also referred to as higher education which encompasses universities, polytechnics, monotechnics, colleges of education, colleges of technology and other allied institutions. However, this education as used in this study, is that of the university. The choice of this institution is based on the premise that it is a degree awarding institution. It is this education that Bogoro (2015) stipulated is positioned to bridge the gap between a productive society and knowledge growth. While achieving this task, Bogoro advocated for a strong collaborative partnership between higher education institutions, government and the industry in what he tagged the 'Triple Helix', the confluence of which the economy of a nation is driven. This view by Bogoro underscores the place of tertiary education in the improvement of the economy. Thus, Bamiro (2015) reported that one of the important prerequisites for the well-being and prosperity of any nation is the sustainable development of industry.

However, in Nigeria which is characterised by dwindling economy, it becomes worrisome as to whether the sustainability of such industries like tertiary education could be achieved considering the responsibility of the government in addressing the various needs of her citizenry and in particular, being the sole sponsor of this education. It is in this end, that policy makers across countries seek to stimulate universities to become more entrepreneurial, engaging more actively with the productive sector in order to generate employment and grow the economy (Dill \& Van-Vught, 2010). In furtherance to this view amidst the economic recession faced by Nigeria, a quest for a pragmatic shift of universities from non-profit making to profit making organisations 
became a topical issue by researchers. This invariably forms the basis of commercialisation of tertiary education in Nigeria, in a recessed economy.

Economic recession, though subjected to variety of definitions denotes a transaction in the economic activity in a country. It is a period of economic slowdown which is characterised by a decline of productivity and devalue of financial institutions resulting from reckless and unsustainable money lending. Hence, Kimberly (2006) stipulated a decline in real gross domestic product, income level of individuals, revenue generation of government, employment, manufacturing and retail sales as some of the economic indicators responsible for recession. The consequences of this economic recession, Adeniran, Adekunle and Adeleke (2017) noted are high interest rates; increased inflation; reduced consumer confidence; and reduced real wages of workers. The decline in these activities may have led to the suggestion of Adeniran and Sidiq (2018) for economic diversification with more emphasis on issue of local contents, education research and innovation as a way out of economic recession in Nigeria.

Commercialisation ordinarily is the act of introducing new product or service into the general market. With regard to education, Swapnali (2016) explained that commercialisation is the trend of decreasing emphasis on the humanities and increasing attention on the demand of the students. Chukwuma, Odiwo and Kifordu (2016) stipulated that commercialisation is the practice of making a profit from services or activities formerly offered free or at a low price to the public. They added that it is the efficient running of a government enterprise with the major motive of making profit. Closely related to these views is that education was originally conceived as humanitarian service provided by the government for the acquisition of requisite skills and knowledge for rational development. However, Muhammed and Abenu (2007) observed that the government alone cannot cope with all the educational needs as the national economic resources dwindled. They added that the universities in Nigeria particularly, operate in adverse conditions of overcrowding, deteriorating physical facilities, shortage of library books, education materials, laboratory consumables and poor maintenance. The inability of the government to adequately and effectively maintain these institutions has resulted to incessant strike by various bodies among which is the ongoing strike by Academic Staff Union of Universities (ASUU).

The above challenges obviously infer the un-attainment of manpower development which is one of the cardinal objectives of any tertiary institutions. Addressing these challenges in the presence of economic recession, Gberevbie, Oni, Oyeyemi and Abasilim (2005) suggested the commercialisation of public enterprises in Nigeria. Interestingly, this commercialisation only came to limelight following the promulgation of the privatization and commercialization Decree in 1988. The decree, according to Chukwuma, Odiwo and Kifordu (2016) gave breath and life to effective public enterprises reforms in Nigeria. In addition, Kretovics and Michaels (2007) indicated that exploring alternative funding; deregulation of policy and regulation; and encouraging alternative funding are three conditions of diversification of funding.

Again, the commercialisation of tertiary education is premised on the fact that private sectors appear to do better in managing the economies. Twebaze (2015) affirmed that commercialisation of education has made running of schools a profit making venture not only in the private schools, but also in the government aided schools. No wonder, it was conceived as an innovative strategy in a number of institutions in China (Tilak, 2003). This is also true as commercialisation of education has generated funds by running businesses, commercialising research for industry, conducting training, development, consultancy and IT services to the public.

The provision of the services through commercialisation of education has in no small measure contributed to the improvement of the economy in any given society. Admitting the contribution of this education, Chijioke (2014) remarked that commercialisation of higher education in West Africa was bound to compromise quality and deny the less privileged, access to higher education. Some scholars while affirming with Chijioke added undue emphasis on academics at the expense of other domains (Twebaze, 2015), and greed for money (Rugumayo, 2009) among others as some of the challenges associated with this education. Whereas the proliferation of 
universities is seen as profit making ventures, its effect in terms of producing qualified manpower that could formulate policies in a recessed economy like Nigeria, has remained doubtful.

The above limitations notwithstanding, do not restrain its contribution in the improvement of the economy. Hence, Swapnali (2016) highlighted some of the benefits of commercialisation of education as creation of employment opportunity, economic development, ability to face global challenges, personality development, increased private institution and development of professional efficiency of teachers. Undoubtedly, most of these merits are tailored to improving the economy of the nation. Suffice it to say that in the midst of economic recession, commercialisation of tertiary education has offered wide range opportunities for wealth creation through engaging the services of various categories of individuals. For instance, institutional reforms were suggested to expand the enterprises in a study on the impact of privatization and commercialisation in Nigeria (Chukwuma, Odiwo \& Kifordu, 2016). This is further true as higher education was conceived as a powerful vehicle of human development that contributes to the economic, social, and political stability of a country. Hence, a study by Twebaze (2015) revealed that commercialisation of education is directed at profit making, rather than the ideals of the noble purpose of education. This study while admitting the flaws in commercialization of education affirms increased revenue. This to a large extent is found to have direct bearing on improvement of the economy and is supported with a study by Ojeifo and Alegbeleye (2015), which recommended full privatization of public enterprise for increased efficiency and contributions to the nation.

In a related development on the contribution of higher education to national development, Kent et al (2005) reported the findings of a study by University of Arizona that there are five major ways higher education influenced the economic well-being of society. These included direct expenditures by the institutions, their employees, and students; provision of financial and other benefits to the individual who pursue advanced education and to society in general and increasingly focused on knowledge creation by institutions of higher education. These findings invariably saw higher education as playing a pivotal and increasingly role of human, social and economic development (Escrigas, 2008). Admittedly, higher education was particularly seen as fundamental to the construction of a knowledge economy and society in all nations. Teboho (2013) gave credence to this view when he posited that the role of higher education in developmen,t encompasses all aspects of development. He added that there is need to keep in mind all aspects of development and not be skewed towards economic development only. The assertion of Teboho recognises various components of development for improved economy. In addition, Heyns (2005) stipulated that higher education contributes to the sustainable development and the improvement of society, as a whole by educating highly efficient graduates, who are able to meet the needs of all sectors of human activities, while advancing, creating and disseminating knowledge through research.

The above views by the various scholars and studies among others, show commercialisation of higher education has some links with improving the economy in any society. Improving the economy suggests an aggressive measure towards controlling recession. Through, adequate training and development of manpower which the tertiary education provides, individuals are said to acquire requisite skills and knowledge to contribute to enacting policies that could improve the economy. However, these changes appear not to have been felt in the society following the widespread inflation prevalent in the scheme of things in Nigeria. In spite of the contributions of commercialisation of government establishment to economic recession in developing nations such as Nigeria, researchers are yet to investigate commercialisation of tertiary education as a correlate of economic recession. The absence of these studies has further created a gap which this present research intends to fill. Hence, this study sets to determine commercialisation of tertiary education as a correlate of economic recession in Nigeria.

The purpose of the study was to determine commercialisation of tertiary education as a correlate of economic recession in Nigeria.

The study was guided by the research question: 
- What is the relationship between commercialisation of tertiary education and economic recession in Nigeria?

The null hypothesis which was tested at .05 level of significance, also guided the study:

- There is no significant relationship between commercialisation of tertiary education and economy recession in Nigeria.

\section{Research Methodology}

The study adopted the correlational survey research design. The population of the study comprised all the lecturers in all the 42 federal universities across the country. The sample size of the study was 1, 648 lecturers drawn from two federal universities. The multi-stage sampling procedure which was used to select five percent of the 42 universities resulted in two federal universities. The purposive sampling technique was further used in selecting the two universities which were University of Port Harcourt in Rivers State and Federal University Otuoke, Bayelsa State. Out of this population, the Taro Yamane formula for the determination of sample size was employed to draw the sample size of 322 lecturers from the two universities, while the convenience sampling was utilised in selecting the lecturers. Instrument for data collection was the researcher's structured questionnaire titled, "Commercialisation of Tertiary Education and Economic Recession (CTEER)". The CTEER was designed on a four point rating scale of strongly agree, agree, disagree and strongly disagree with numerical values of $4,3,2$, and 1 respectively.

The validity of the instrument was established using three experts from the University of Benin, Edo State. The reliability coefficient value of .83 was obtained after a trial testing at University of Calabar using the Cronbach Alpha statistic tool. Data collected were analysed using the Pearsons' Correlation Coefficient and Co-efficient of Determination to answer the research question. The classifications of relationship were as follows : $0.00-0.20$ (very low relationship), $0.21-0.40$ (low relationship), $0.41-0.60$ (moderate relationship); $0.61-0.80$ (high relationship) and $0.81-1.00$ (very high relationship). The linear regression was used to test the null hypothesis at .05 level of significance. With the probability value greater than .05 level of significance, the null hypothesis was not accepted, but where the probability value is less than .05 level of significance, the null hypothesis was accepted.

\section{Results of findings}

\subsection{Answer to research question}

What is the relationship between commercialization of tertiary education and recessed economy in Nigeria.

Table 1: Pearson's Correlation Coefficient on Commercialization of Tertiary Education and Recessed Economy

\begin{tabular}{lllllll}
\hline Variable & Mean & Std & No & r & $\mathbf{R}^{2}$ & Remark \\
\hline $\begin{array}{l}\text { Commercialisation of } \\
\text { tertiary education }\end{array}$ & 2.97 & 0.24 & & & & Very \\
\begin{tabular}{l} 
Economic recession \\
\hline
\end{tabular} & 2.94 & 0.25 & 319 & 0.81 & 0.66 & $\begin{array}{l}\text { High } \\
\text { Relationship }\end{array}$ \\
\hline
\end{tabular}

$a=0.05, R^{2}=$ Co-efficient of determination

Table 1 showed the relationship between commercialisation of tertiary education and economic recession in Nigeria. The result obtained indicated that the correlation coefficient was 0.81 . This means that there is an existence of a very high relationship between commercialisation of tertiary education and economic recession in Nigeria. The Table further indicated that the co-efficient of determination $\left(\mathrm{R}^{2}\right)$ associated with the correlation coefficient of 0.81 was 0.66 . This co-efficient of determination therefore implied that $66 \%$ of economic recession in Nigeria is attributed to commercialisation of tertiary education. The implication of this is that $34 \%$ of economic recession in Nigeria is caused by other variables other than commercialisation of tertiary education. 
3.2 Test of Hypothesis: There is no significant relationship between commercialization of tertiary education and recessed economy in Nigeria.

Table 2: Regression Analysis of Commercialization of Tertiary Education and Economic

\begin{tabular}{lcrcrc}
\hline Variable & $\begin{array}{l}\text { Unstandard } \\
\text { Coefficient } \\
\mathrm{B}\end{array}$ & Std. Error & $\begin{array}{l}\text { Standard } \\
\text { Coefficient } \\
\text { Beta }\end{array}$ & $\mathrm{t}$ & Sig. value \\
\hline Constant & 2.98 & 0.71 & -0.01 & -0.24 & 0.81 \\
$\begin{array}{l}\text { Commercialisation } \\
\text { Of Tertiary Edu. }\end{array}$ & -0.01 & .06 & & & \\
\hline
\end{tabular}

$F$-value $=0.06, R$-Square $=0.00, R-$ Square Change $=0.00$

Table 2 showed that the t-value for commercialisation of tertiary education was -0.24 at the probability value of 0.81 and significant level of 0.05 . Since the p-value $(0.81)$ is greater the .05 level of significance, the null hypothesis is hereby accepted. This means that a significant relationship does not exist between commercialisation of tertiary education and economic recession in Nigeria.

\section{Discussion of Findings}

One of the findings of the study is the existence of very high relationship between commercialisation of tertiary education and economic recession in Nigeria. This may be true as commercialisation of tertiary education was conceived as an efficient running of government enterprise with the major motive of making profit. (Chukwuma, Odiowo \& Kifordu, 2016). Admitting that the maintenance of tertiary education is capital intensive, which government alone cannot handle especially in a recessed economy, the finding also concurred with the view of Kretiovics and Michaels (2007) on exploring alternative funding as the conditions to diversification of funding.

Commercialisation of tertiary education therefore could be seen as such avenue where funds are raised alternatively following the expansion of many institutions with the creation of more job opportunities. This collaborates with the view of Swapnali (2016) that commercialisation of education has contributed to economic development among others. This invariably implies that with the proliferation of these institutions, individuals are given the opportunities to work, earn and contribute to the dwindling economy so as to improve the gross domestic product. This view is in tandem with the recommendation of Adeniran and Sidiq (2018) of economic diversification as a prerequisite to overcoming economic recession in Nigeria.

On the contrary, the study further revealed the existence of no significant relationship between the commercialisation of higher education and economic recession in Nigeria. This existence of no relationship shows that although, commercialisation of tertiary education has contributed to the economic development of the country, through the various services provided, it was however seen as not overcoming economic recession. This may probably be as a result of other extraneous variables or factors employed by the federal government in the deregulation of policies. This idea may have further informed Bogoro (2015) to state that tertiary education was a bridge between productive society and knowledge growth. The implication of this view is that the education is concerned with the inculcation of right knowledge on the individual in order to make policies that could help improve the economy of the society. Such policies among others are evident in the control of economic recession.

\section{Conclusion}

Commercialisation of tertiary education in Nigeria was an innovative strategy aimed at generating revenue for the country to improve the economy. Through this process, various economic activities were established, thus, imploring the services of different categories of individuals in the promotion of the economy. This strategy entails a pragmatic shift from offering humanitarian services which hitherto was provided by the government to 
profit making ventures. Although, identified as one of the ways of improving the economy, other factors were found to play significant role in the control of economic recession in Nigeria.

\section{Recommendations}

The following recommendations were made:

- The government through the various commissions responsible for monitoring and supervising the activities of tertiary institution, should ensure intensification of quality assurance mechanisms in tertiary education system.

- Policy makers should ensure policies capable of addressing the immediate problem of the society are incorporated into curricula and enforced in the school system

- Awareness through the use of electronic media should be intensified to sensitise the populace on the various services that are offered by the tertiary institutions.

\section{REFERENCES}

Adeniran, A. O. \& Sidiq, B. O. (2018). Economic recession and the way-out. Nigeria as case study. Global Journal of Human Social: Economics, 18(1), 1-6.

Adeniran, A. O., Adekunle, E. A. \& Adeleke, I. A. (2017). The pertinency of fuel subsidy in Nigeria's economic recession. International Journal of European Studies, 1(3), 60 - 71.

Bogoro, S. E. (2015). Enhancing the Relevance of Research and Industry Partnership in Nigeria: A Case for New Strategies. Convocation lecture delivery at the 2015 convocation ceremony of the Federal University of Technology, Owerri, Dec. 3

Chijioke, O. (2014). Gambian Minister Decries Commercialisation of Higher Education in Africa. News agency of Nigeria. Available: www.nannewsnigeria.com.

Chukwuma, C. S., Odiwo, W. O. \& Kifordu, A. A. (2016). The Impact of Privatization and Commercialization in Nigeria. International Research Journal of Management, IT and Social Sciences (IRJNUS), 3 (9), 91 -102 .

Dill, D. \& Van-Vught, F.(2010). National Innovation and the Academic Research Enterprise. Baltimore, MD: John Hopkins University Press.

Escrigas, C. (2008). Forward in Guni Higher Education in the World 3. London: Palgrave McMillan.

Federal Republic of Nigeria (FRN) (2014). National Policy on Education. Lagos: NERDC.

Gberevbie, D. S. Oni, S., Oyeyemi, A., \& Abasilim, U. D. (2015). Privatization of Public Enterprises: Which Way Nigeria? Ecofrum, 4 (1), 33 - 45.

Kent, H. et al (2005). The value of higher education: individual and societal benefits. Arizona State University, October 4.

Kimberly, A. (2016). Recession, examples, impacts and benefits.

Kretovics, M. \& Michaels, S. O. (2007). Financing Higher Education in a Global Market. New York: Algora Publishing.

Muhammed, M. O. B. \& Gbenu, J. P. (2007). Public Universities on the Brink of Collapse in Nigeria: Private Sector Participation as a way out. In J. B. Babalola, G. O. Akpa, A. O. Ayeni and S. O. Adedeji, Access, Equity and Quality in Higher Education. Ibadan: Awemark.

Ojeifo, A. \& Alegbeleye, G. I. (2015). Public enterprise and sustainable socio-economic development in Nigeria. Review of Public Administration and Management, 4(8), 51 - 62.

Rugumayo, E. (2013). Re-envisioning higher education in Africa. African Journal of Higher Education Studies and Development (AJESD), 1(2), 133 - 158.

Swapnali, B. (2016). Commercialisation of education system: A critical analysis. International Research Journal of Interdisciplinary and Multidisciplinary Studies. (IRJIMS), 1(xii), 71 - 76.

Tilak, J. (2003). Higher education and development in Asia. Journal of Educational Planning and Administration, 17(2), $151-173$.

Twebase, R. M. (2015). Commercialisation of education in Uganda: Causes and consequences. International Journal of Recent Scientific Research,6(7), 5107-5112. 